\title{
Anatomia foliar de espécies de Xylopia L. (Annonaceae) ocorrentes no Parque Ecológico de Gunma, Santa Bárbara, estado do Pará

\author{
Leaf anatomy of Xylopia L. (Annonaceae), occurring in
} Ecological Park of Gunma, Santa Bárbara, Pará State
}

\author{
Eliane Francisca de Almeida! \\ Raimunda Conceição de Vilhena Potiguara"I \\ Eunice Gonçalves Macedo'II \\ Alba Lúcia Ferreira de Almeida Lins ${ }^{\mathbb{V}}$
}

Resumo: Annonaceae apresenta várias espécies produtoras de óleos essenciais, entre estas as do gênero Xylopia, que apresentam propriedades medicinais, farmacológicas e biológicas. Dessa forma, o presente estudo tem como objetivo conhecer a anatomia foliar, identificar e localizar as estruturas secretoras, além de realizar testes histoquímicos nas espécies Xylopia benthamii R.E. Fries e $X$. nitida Dunal. Para a realização desse estudo, foram confeccionadas lâminas de dissociação de epidermes, maceração, cortes histológicos e testes histoquímicos, de acordo com os protocolos usuais em anatomia vegetal, utilizando-se a microscopia de luz e a eletrônica de varredura. Os resultados mostraram que as duas espécies diferenciaram-se quanto ao contorno das paredes anticlinais na superfície adaxial, presença de superfície abaxial papilosa, margem terminando com feixes vasculares, estômatos posicionados abaixo do nível das células epidérmicas, estriamento cuticular e presença da nervura marginal. Diante dos resultados, a anatomia foliar auxiliou na distinção dos taxa estudados e possibilitou a localização das estruturas secretoras nas duas espécies estudadas.

Palavras-chave: Xylopia benthamii. Xylopia nitida. Estruturas secretoras.

\begin{abstract}
Annonaceae shows several species which are producers of essential oil, among them Xylopia genus, that shows medicinal, pharmacological and biological properties. Thereby the present study has the purpose of knowing leaf anatomy, identify and locate secretory structures, besides to realize histochemical tests in Xylopia benthamii R.E. Fries and X. nitida Dunal species. Slides of epidermal dissociation were prepared to carry out this study, maceration, histological cuts and histochemical tests, according to usual protocols in plant anatomy, using optical light microscopy and electronic scanning. The results showed that both species differed in epidermal cell walls shape on adaxial surface, they present papillose abaxial surface, margin ending in vascular bundles, the stomata is located under epidermal cell level, striate cuticle and marginal vein presence. Before the results, the leaf anatomy of taxa studied helped to segregate them and made it possible to locate the secretory structures on both studied species.
\end{abstract}

Keywords: Xylopia benthamii. X. nitida. Secretory structures.

Museu Paraense Emílio Goeldi. Belém, Pará, Brasil (efalmeida@museu-goeldi.br).

Museu Paraense Emílio Goeldi. Belém, Pará, Brasil (raipoty@museu-goeldi.br).

III. Universidade do Estado do Pará. Centro de Ciências Naturais e Tecnológicas. Belém, Pará, Brasil (eunicemacedo@yahoo.com.br).

v Museu Paraense Emílio Goeldi. Belém, Pará, Brasil (lins@museu-goeldi.br).






\section{INTRODUÇÃO}

A região amazônica é caracterizada por apresentar uma das maiores diversidades vegetais do mundo. Neste imenso contingente florístico, destacam-se as plantas aromáticas e medicinais, dentre as quais é possível destacar as espécies pertencentes à Annonaceae. Esta família é composta por cerca de 130 gêneros e 2.300 espécies, com distribuição pantropical (Cronquist, 1981), sendo representada, na região neotropical, por, aproximadamente, 40 gêneros e 900 espécies (Chatrou et al., 2004), dos quais 30 gêneros e 270 espécies foram registrados para a Amazônia (Oliveira, 1997).

Segundo Ribeiro et al. (1999), os representantes dessa família podem ser reconhecidos pelo odor forte que exalam do tronco ou de ramos, quando estes são cortados. Esta prática é usada para auxiliar a identificação das espécies. Os mesmos autores citam ainda que vários representantes de Annonaceae são utilizados na indústria de perfumaria, construção civil, na medicina popular e alimentícia.

Para Leboeuf et al. (1982), muitas espécies de Annonaceae apresentam óleos essenciais que, normalmente, são constituídos de monoterpenóides, sesquiterpenóides e/ ou substâncias aromáticas. Dentre as espécies do gênero Xylopia, Alexander et al. (1991) afirmam que muitas possuem atividade biológica devido apresentarem, na sua composição química, alcalóides e compostos voláteis, flavonóides, terpenóides e esteróis.

Apesar de Annonaceae ter importância econômica e farmacológica, são poucos os estudos sobre a anatomia foliar, principalmente quando se referem às espécies do gênero Xylopia L. Entre estes trabalhos, destacam-se os realizados por Morretes \& Ferri (1959), ao estudarem a anatomia das folhas de Xylopia grandiflora A. St.-Hil.; Silva \& Grotta (1975), que investigaram a anatomia foliar de Xylopia frutescens Aubl.; Santos et al. (2004), que estudaram os aspectos da anatomia e do óleo essencial de pindaíba (Xylopia brasiliensis Spreng.) e de Justos et al. (2005), que estudaram a plasticidade anatômica das folhas de Xylopia brasiliensis Spreng.

Diante do exposto, objetivou-se estudar a anatomia foliar, identificar e localizar as estruturas secretoras e realizar testes histoquímicos nas espécies Xylopia benthamii R.E. Fries e Xylopia nitida Dunal, visando auxiliar a distinção dos referidos taxa.

\section{MATERIAL E MÉTODOS}

Indivíduos de Xylopia benthamii e $X$. nitida foram coletados no Parque Ecológico do Gunma, localizado no município de Santa Bárbara, Pará, distando 34,8 km de Belém. O clima é do tipo tropical Afi, de acordo com a classificação climática de Köppen, caracterizandose por apresentar temperatura média de $18^{\circ} \mathrm{C}$, com precipitação pluviométrica maior ou igual a $60 \mathrm{~mm}$ no mês mais seco (Almeida et al., 2003). A vegetação é composta por floresta ombrófila (úmida) densa de terra firme, sendo o ambiente mais representado pela floresta secundária (capoeira) latifoliada, igapó e várzea. Os solos que ocorrem no Parque são de três tipos: Latossolos Amarelos Álicos, Concrecionário Laterítico Álico e Gley Pouco Úmido.

Para o estudo anatômico, foram utilizadas folhas in natura coletadas dos indivíduos das espécies de Xylopia benthamii e X. nitida. As folhas de Xylopia benthamii foram retiradas dos indivíduos registrados nos inventários florísticos realizados por Almeida et al. (2003), sob o registro do inventário sete, na parcela dois e número 21, e do inventário 16, parcela nove e de número 212. As folhas de $X$. nitida foram obtidas dos indivíduos registrados sob o número 131 e 133 da parcela seis, e do indivíduo com número 285 da parcela dois, conforme levantamento florístico realizado por Leão et al. (2005).

Foram utilizadas folhas do $4^{\circ}$ e $5^{\circ}$ nó para a realização dos estudos anatômicos. Posteriormente, o material coletado foi fixado em FAA 70 e acondicionado em etanol 70\% (Johansen, 1940).

Com relação ao estudo da epiderme em vista frontal, o material foi imerso em solução de Jeffrey a 10\% (Johansen, 1940), coradas com azul de astra e fucsina básica (Gerlach, 1984), desidratada em série etanólica e aceto-butílica crescente (Kraus \& Arduin, 
1997), sendo montadas entre lâmina e lamínula em bálsamo-do-canadá.

Os cortes histológicos foram obtidos das três regiões da folha (ápice, meio e base) e pecíolo com auxílio de lâmina de barbear, usando cortiça como suporte, clarificados e corados com azul de astra e fucsina básica (Gerlach, 1984) e montados entre lâmina e lamínula em glicerina diluída, vedando as bordas da lamínula com esmalte incolor.

Para a confecção de lâminas permanentes, o material fixado em FAA 70 foi seccionado na região do pecíolo e na região mediana da folha e desidratado pelas séries etanólica e etanólica-acetobutílica crescente, infiltrado e incluído em parafina histológica, de acordo com o protocolo de Kraus \& Arduin (1997). Posteriormente, os blocos foram cortados com o auxílio de micrótomo rotativo, com espessura variando entre 8 e $10 \mu \mathrm{m}$ e distendido em lâmina albuminada. Após 24 horas, os cortes foram submetidos à série etanólicaacetobutílica decrescente, corados com azul de astra e fucsina básica (Gerlach, 1984). Em seguida, os cortes sofreram a ação de desidratação pela série etanólicaacetobutílica crescente e foram montados entre lâmina e lamínula em resina sintética.

Os testes histoquímicos foram realizados nos cortes à mão livre de material in natura e clarificados em hipoclorito. Os reagentes utilizados estão demonstrados na Tabela 1.

Para a observação da cera epicuticular, utilizou-se a microscopia eletrônica de varredura, e as amostras foram processadas em secador de ponto crítico, montadas em stubs e metalizadas com ouro (Silveira, 1989).
O estudo de venação foi realizado com folhas inteiras e secções da região mediana (entre margem e nervura central), que foram imersas em solução de hidróxido de sódio a 20\% (Arnott, 1959). Essas amostras foram coradas com safranina hidro-alcoólica 1\% (Johansen, 1940). Em seguida, o material foi desidratado em série etanólica crescente e aceto-butílica (Kraus \& Arduin, 1997). A folha inteira foi montada entre placas de vidro e as secções entre lâmina e lamínula, ambas em bálsamo do canadá. As descrições do padrão de venação foram feitas de acordo com o Leaf Architecture Working Group (1999).

As lâminas foram fotomicrografadas com auxílio de câmera fotográfica digital, acoplada ao microscópio de luz, no Laboratório de Microscopia do Museu Paraense Emílio Goeldi (MPEG). As eletromicrografias foram obtidas em microscópio eletrônico em aceleração de 10 a $15 \mathrm{Kv} \mathrm{e}^{\circ}$

\section{RESULTADOS E DISCUSSÃO}

Em vista frontal, as espécies estudadas apresentaram, na superfície adaxial, células epidérmicas de vários tamanhos, sendo que em Xylopia benthamii as células epidérmicas são irregulares com paredes anticlinais sinuosas (Figura 1A), enquanto que em $X$. nitida as células epidérmicas são poligonais com paredes anticlinais retas (Figura 1B). As células epidérmicas que revestem as nervuras principal e secundárias dos taxa estudados, tanto da superfície adaxial (Figuras 1C e 1D) quanto da abaxial (Figuras 2C e 2D), acompanham longitudinalmente as mesmas, e as paredes anticlinais

Tabela 1. Testes histoquímicos empregados para a identificação de impregnações das paredes e inclusões celulares.

\begin{tabular}{c|c|c|c}
\hline Substância & Reagente & Reação & Autor \\
\hline Amido, celulose, pectina & Lugol & Roxa à negra & Johansen, 1940 \\
Óleos, ceras, resinas, cutina, suberina & Sudan III & Vermelha & Johansen, 1940 \\
Lignina & Floroglucina & Jermelha & Chansen, 1940 \\
Oxalato de cálcio & $\begin{array}{l}\text { Ácido clorídrico } \\
\text { Ácido acético }\end{array}$ & Diluição & Chberlain, 1938 \\
\hline
\end{tabular}

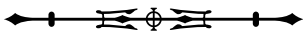



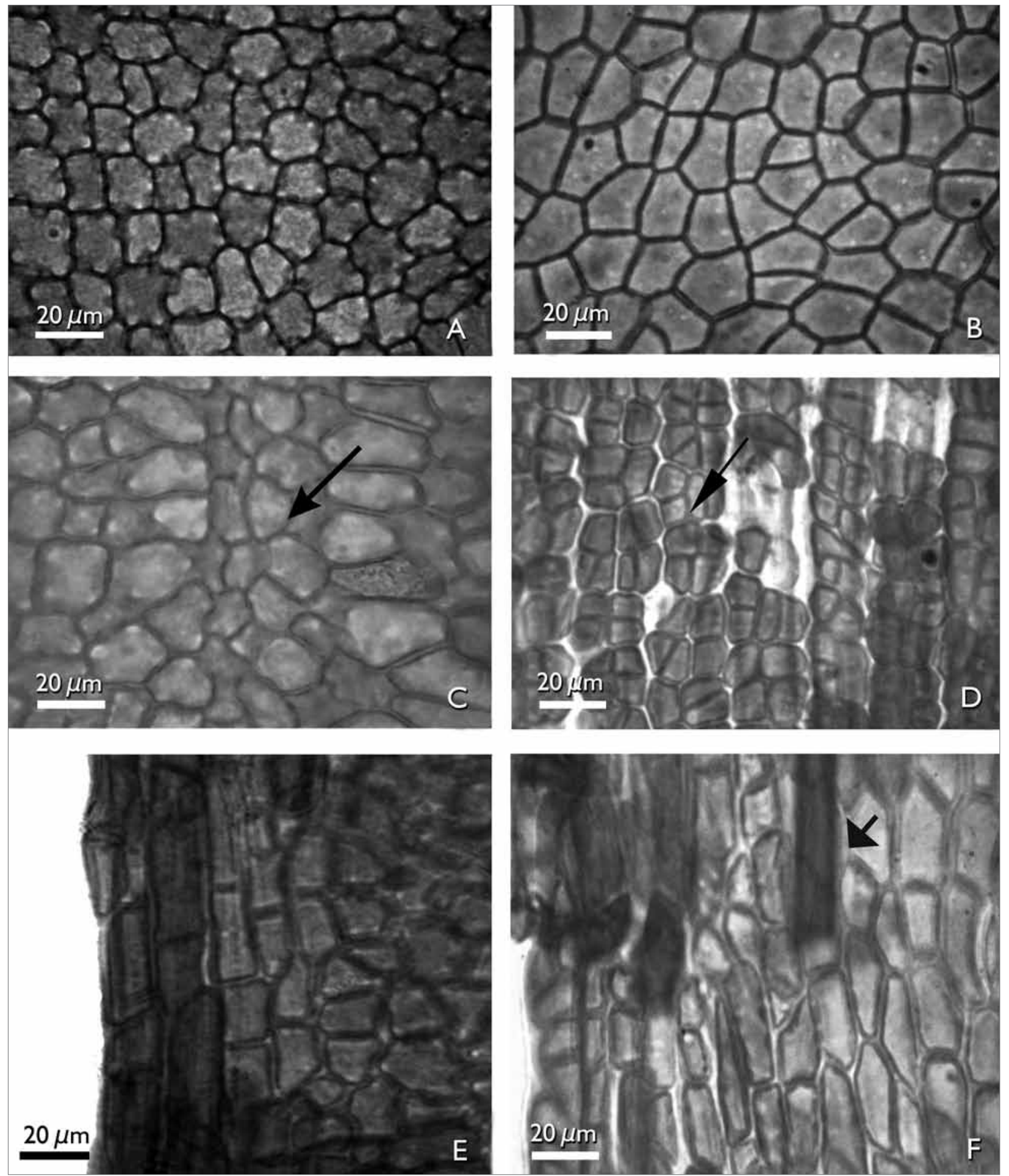

Figura 1. Vista frontal da superficie adaxial da epiderme de Xylopia L.: A, C e E - X. benthamii. B, D e F-X. nitida. A e B - vista geral; C e D - detalhe das células da nervura central; E e F - detalhe das células da margem. Seta maior indica nervura central. Seta menor indica tricoma. 



Figura 2. Vista frontal da superfície abaxial das espécies de Xylopia L.: A e C - X. benthamii. B e D - X. nitida. A e B - vista geral da superfície; C e D - detalhe das células da nervura central. Seta maior indica tricoma filiforme (Tf). Seta menor indica estômatos (est).

são retas. A diferença principal é que as da superfície adaxial são mais curtas e as da abaxial são alongadas.

As células epidérmicas que se localizam nas proximidades da margem em $X$. benthamii são de diferentes tamanhos, sendo, na sua maioria, tabulares (Figura 1E), enquanto que em $X$. nitida as mesmas são, na sua maioria, irregulares, com forma variando de retangulares a tabulares (Figura 1F). Percebe-se, ainda, que na região marginal das espécies estudadas há presença de tricomas unicelulares, principalmente em $X$. nitida (Figura 1F).

A superfície abaxial de $X$. benthamii e $X$. nitida em vista frontal apresenta entre as células epidérmicas tricomas e estômatos (Figuras 2A e 2B). As células

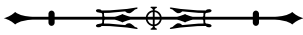


epidérmicas abaxiais de $X$. benthamii são irregulares, de paredes anticlinais levemente sinuosas (Figuras $3 \mathrm{C}$ e $5 \mathrm{~A}$ ), enquanto que em $X$. nitida as células apresentam a parede anticlinal reta (Figuras 2B e 5B) e a parede periclinal externa com projeções levemente acentuadas, semelhante a uma papila (Figuras 3D e 5D). A presença de papilas na epiderme abaxial para as espécies de Annonaceae foi reportada por Metcalfe \& Chalk (1950), ao estudarem a anatomia geral da família, porém, estes autores não fizeram referência ao gênero Xylopia. Napp-Zinn (1988 apud Vieira \& Gomes, 1995) relatou que as papilas possuem funções de proteção contra a perda de água pelos estômatos e de captação de estímulos luminosos.

A ocorrência de paredes sinuosas em $X$. benthamii corrobora os resultados encontrados por Justos et al. (2005) para a espécie $X$. brasiliensis. Em $X$. nitida, as paredes anticlinais são retas, semelhantes às encontradas por Silva \& Grotta (1975) e Morretes \& Ferri (1959), ao estudarem as espécies $X$. frutescens e $X$. grandiflora. Solereder (1908) cita que a sinuosidade das paredes anticlinais é um caráter taxonômico importante na separação das espécies de Annonaceae, característica usada na separação das espécies estudadas.

A cutícula dos taxa estudados em microscopia eletrônica de varredura é lisa em ambas superfícies de $X$. nitida (Figuras 3B e 3D), com exceção das nervuras secundárias, que são levemente estriadas (Figura 3E). Em $X$. benthamii, a cutícula na superfície adaxial também é lisa (Figura 3A), porém, na superfície abaxial, é estriada, característica usada na distinção dos taxa estudados (Figura 3C). Esse caráter também é reportado para Rollinia mucosa (Jacq.) Baill. por Albarello et al. (2001). As espécies $X$. benthamii e $X$. nitida apresentam sobre a cutícula, tanto na superfície abaxial quanto na adaxial, uma densa camada de cera epicuticular do tipo escamosa (Figuras 4A e 4B).

Para os autores Wilkinson (1979) e Alquini et al. (2003), a ornamentação da cutícula é característica de plantas de ambientes xéricos ou folhas de sol, enquanto que cutícula lisa é característica de espécies mesofíticas, hidrófitas ou de folhas de sombra. Os mesmos autores afirmam que a ornamentação da cutícula tem a função de proteção contra a perda de água e contra o excesso de luminosidade, podendo ser usada como caráter diagnóstico taxonômico. Esta afirmação da ornamentação cuticular não procede em relação às espécies estudadas, já que $X$. nitida encontra-se em ambiente mais exposto à radiação solar.

A cera epicuticular destaca-se como a principal barreira protetora contra perda de água por transpiração excessiva, ação de patógenos, radiações solares e entradas de produtos químicos e contaminantes, conforme Heredia et al. (1998) (apud Monquero et al., 2004). Do ponto de vista taxonômico, segundo Wilkinson (1979) e Alquini et al. (2003), a forma como a cera epicuticular se deposita sobre a superfície foliar pode ser considerada como um caráter diagnóstico. Nas espécies estudadas, esse caráter não apresenta importância taxonômica, já que em ambas a cera epicuticular é semelhante.

Ambas as espécies estudadas apresentam tricomas simples, pluricelulares com uma a três células, filiformes, afilando-se da base para o ápice (Figuras 2A e 2B), com a base inserida entre seis a sete células epidérmicas (Figuras 5E e 5F), as quais evidenciaram estriações longitudinais. Até então, estas estriações não foram referidas a outras espécies de Xylopia. Morretes \& Ferri (1959) citam apenas a presença de tricomas unicelulares para $X$. grandiflora, enquanto que Metcalfe \& Chalk (1950), Solereder (1908), Patel (1971) e Justos et al. (2005) relatam a presença de tricomas simples e pluricelulares para várias espécies da família Annonaceae.

Os estômatos observados para espécies $X$. benthamii e $X$. nitida são paracíticos (Figuras 5A, 5B, 5C e 5D). O tipo paracítico é reportado por Metcalfe \& Chalk (1950), Patel (1971), Silva \& Grotta (1975) e Justos et al. (2005) como comum à família. Em X. benthamii, os estômatos estão levemente acima das demais células epidérmicas (Figura 5C), enquanto que em $X$. nitida 

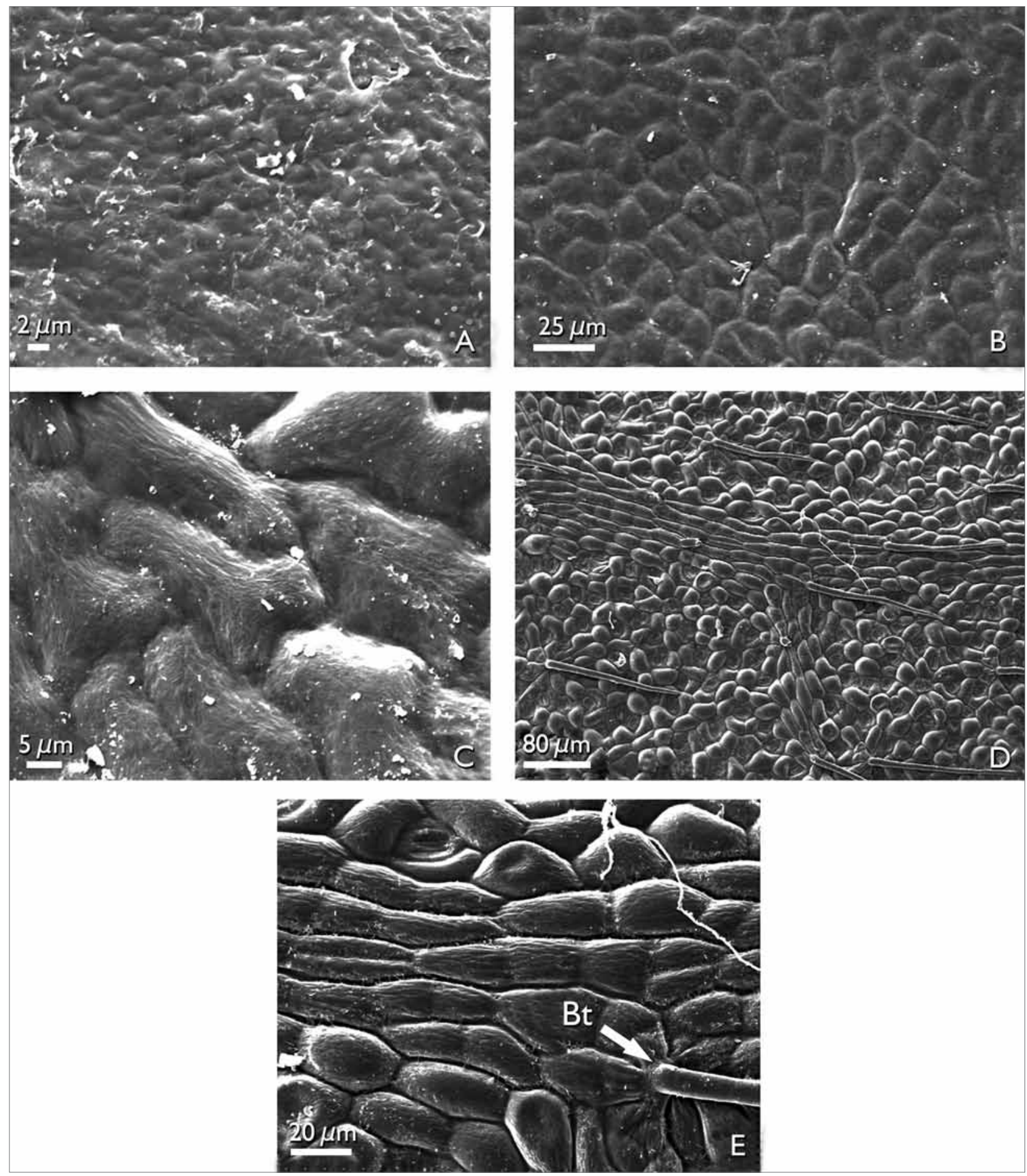

Figura 3. Eletromicrografia de varredura da superfície foliar das espécies de Xylopia L.: A e C - X. benthamii. B, D e E - X. nitida. A e B - vista geral da superfície adaxial, evidenciando cutícula lisa; C - superfície abaxial, mostrando cutícula levemente estriada; D - superfície abaxial, mostrando cutícula lisa e epiderme papilosa; E - detalhe das células epidérmicas sobre a nervura secundária, evidenciando cutícula levemente estriada. Seta indica base de tricoma (Bt). 

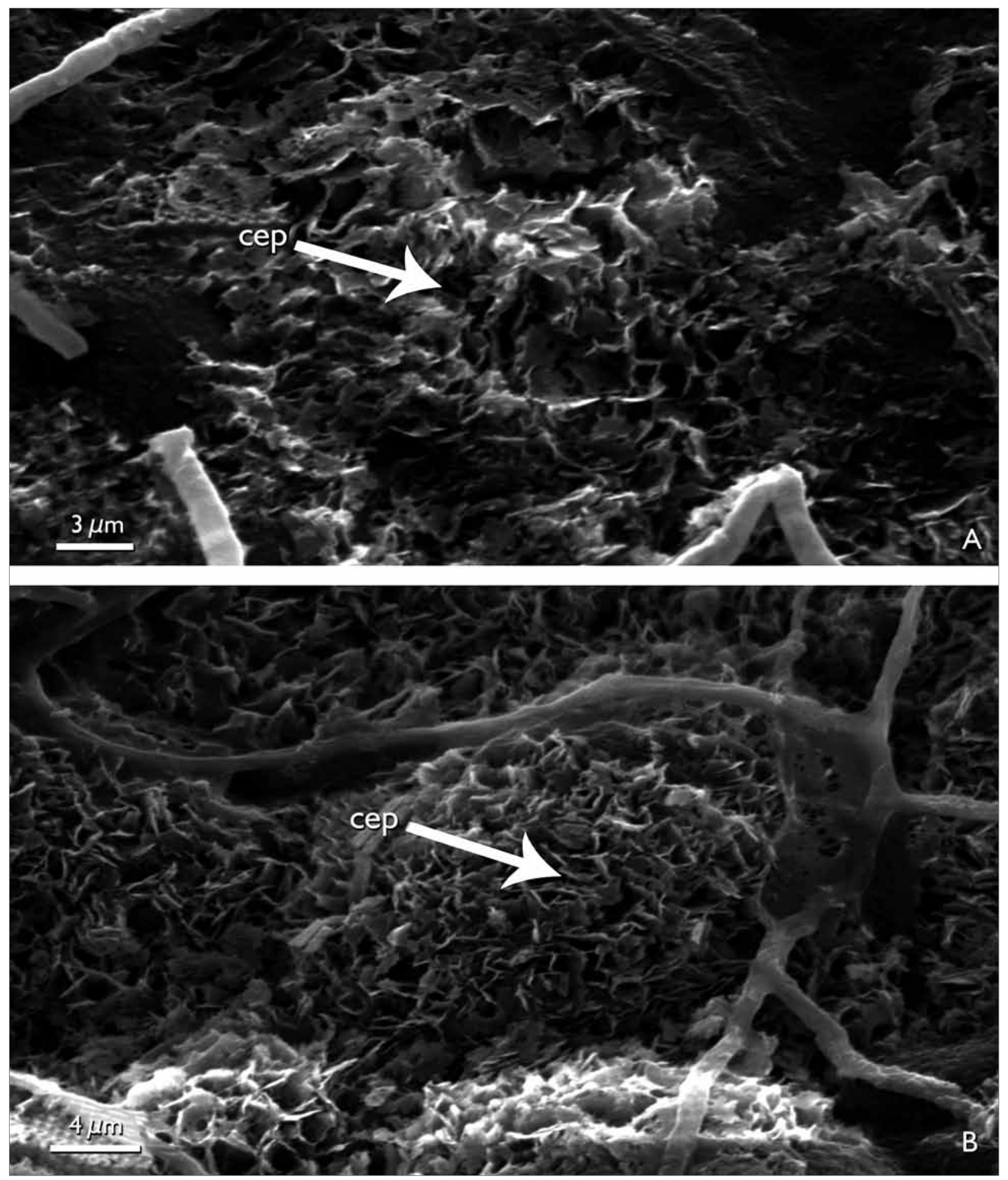

Figura 4. Eletromicrografia de varredura da cera epicuticular do tipo escama da superfície foliar de Xylopia L.: A - face abaxial de X. benthamii; B - face adaxial de $X$. nitida. Cera epicuticular (cep). 

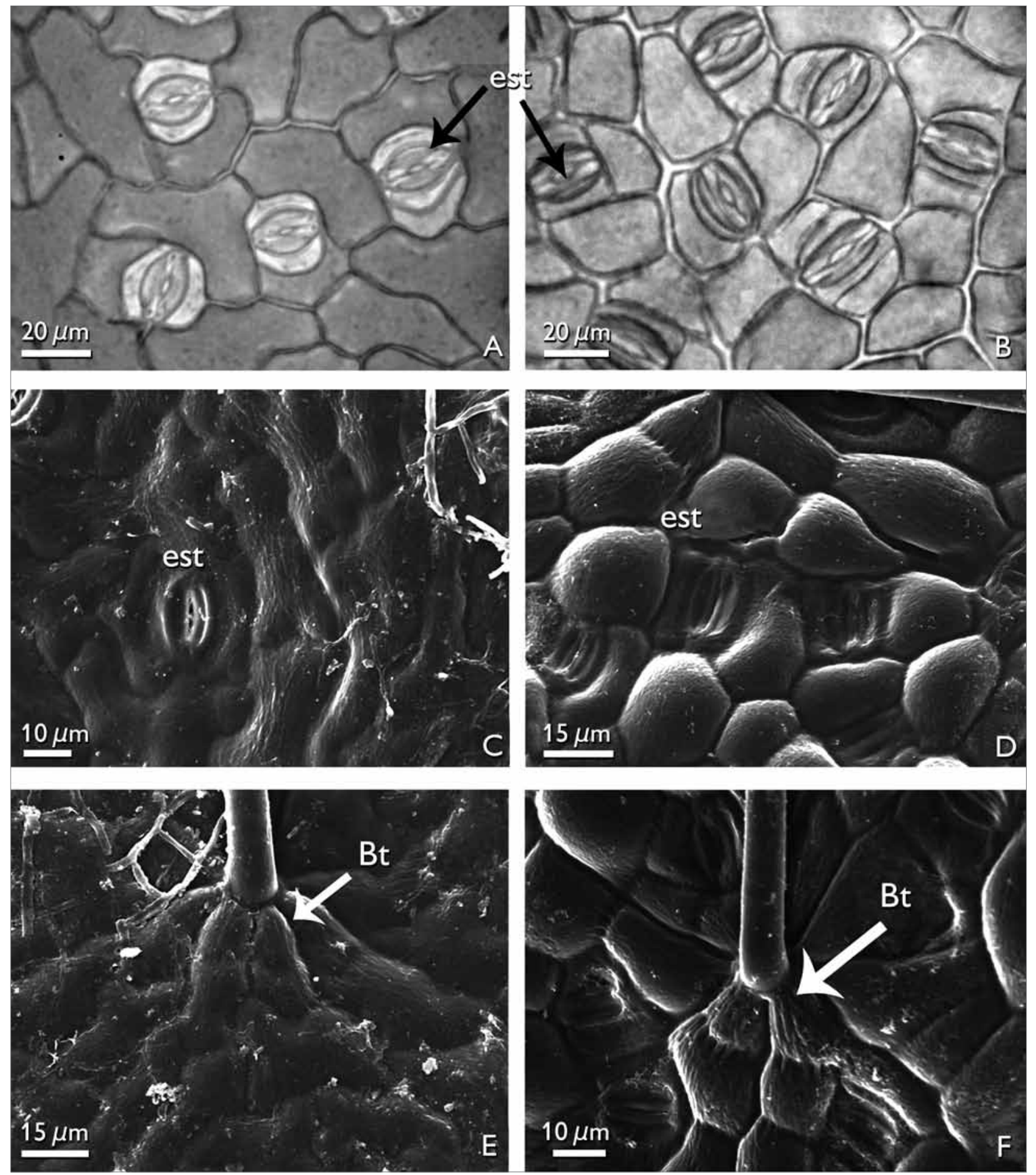

Figura 5. Superfície abaxial da epiderme foliar de Xylopia L.: A, C e E-X. benthamii. B, D e F-X. nitida. A e B-fotomicroscopia evidenciando as células epidérmicas, estômatos paracíticos e as demais células epidérmicas; C - eletromicrografia dos estômatos levemente acima das demais células epidérmicas; $\mathrm{D}$ - estômatos levemente abaixo do nível das demais células; E e F- eletromicrografia do detalhe da base do tricoma filiforme em roseta e as estrias longitudinais nas demais células epidérmicas. Estômatos (est). Base do tricoma (Bt). 
ficam levemente abaixo do nível das demais células epidérmicas (Figura 5D).

A lâmina foliar das espécies estudadas, em secção transversal, é dorsiventral (Figuras 6A e 6B). Metcalfe \& Chalk (1950) e Solereder (1908) afirmam que a dorsiventralidade das folhas para as espécies pertencentes à Annonaceae é comum, conforme também observado em X. frutescens por Silva \& Grotta (1975), e em X. brasiliensis por Santos et al. (2004) e Justos et al. (2005).

Em $X$. benthamii, ambas as faces epidérmicas são uniestratificadas, com células de diferentes tamanhos, retangulares, de paredes anticlinais e periclinais retas (Figuras 6C, 6E e 6G), embora, na face adaxial, apresentem a parede periclinal externa levemente invaginada (Figuras 6C e 6E). Entretanto, em X. nitida, a epiderme adaxial é multisseriada, com duas a quatro camadas de células de vários tamanhos, retangulares, com paredes anticlinais e periclinais retas, sendo que a última camada, mais interna, é mais desenvolvida em relação às demais, sendo estas retangulares, sem conteúdo, semelhantes a uma hipoderme (Figuras 6B, 6D e 6F). Ainda nesta espécie, nota-se que, na face abaxial, as células epidérmicas são de diferentes tamanhos, variando de retangulares a arredondadas, com paredes anticlinais e a periclinal interna retas, enquanto que a parede periclinal externa é côncava, semelhantes a papilas (Figura $6 \mathrm{H}$ ).

Epiderme uniestratificada é reportada nos trabalhos de Santos et al. (2004) e Justos et al. (2005), ao estudarem as folhas de $X$. brasiliensis; epiderme multisseriada é citada por Metcalfe \& Chalk (1950) para espécies de Xylopia e por Silva \& Grotta (1975) para folhas de $X$. frutescens; e hipoderme é citada por Morretes \& Ferri (1959) para a segunda camada de células na espécie $X$. grandiflora. Entretanto, neste trabalho, não se utilizou o termo hipoderme pelo fato de ser necessária a realização de estudos ontogenéticos, o que não foi objetivo deste estudo, referindo-se à epiderme multisseriada para $X$. nitida.
Nas células epidérmicas adaxiais de ambas as espécies observam-se cristais do tipo drusas de oxalato de cálcio (Figuras 6E e 6F), o que está de acordo com as observações feitas por Solereder (1908) e Metcalfe \& Chalk (1950) para Annonaceae, por Silva \& Grotta (1975) para $X$. frutescens, e também por Justos et al. (2005) para a lâmina foliar de $X$. brasiliensis.

mesofilo em secção transversal visto nas espécies estudadas apresenta a base dos tricomas com parede espessada e lignificada, sendo a mais interna voltada para o lúmen e comprimida, o que, provavelmente, decorre do fato de o tricoma ser adpresso (Figuras 7A e 7B).

mesofilo dos taxa estudados é dorsiventral e o parênquima paliçádico é biestratificado (Figuras 6A e 6B). Em X. benthamii, a camada paliçádica chega a apresentar até três camadas de células, principalmente nas proximidades dos feixes vasculares, característica que não foi observada em $X$. nitida. O parênquima lacunoso, em ambas as espécies, é constituído por quatro a seis camadas de células irregulares com espaços intercelulares (Figuras 6A, 6B, 6G e 6H).

No mesofilo da lâmina foliar de $X$. benthamii e $X$. nitida, é comum a presença de feixes vasculares colaterais e cavidades secretoras (Figuras 6A, 6B, 7C e 7E). Os feixes vasculares secundários apresentam o floema voltado para a face abaxial, e o xilema para a face adaxial. Estes podem ou não ser envolvidos por bainha esclerenquimática, formando ou não extensão de bainha e, quando isso ocorre, atingem a epiderme adaxial (Figuras 6A, 6B, 7C, 7E e 7F).

As cavidades secretoras, em ambas as espécies, estão distribuídas aleatoriamente por todo o mesofilo, sendo arredondadas e/ou ovais (Figuras 6A, 6B, 7C e 7D). Essas cavidades apresentam substâncias lipídicas, identificadas pelo teste de Sudan III (Johansen, 1940) (Figura 7D).

Morretes \& Ferri (1959), ao analisarem as folhas de $X$. grandiflora, definem a cavidade secretora como uma grande câmara de contorno quase circular. Silva 


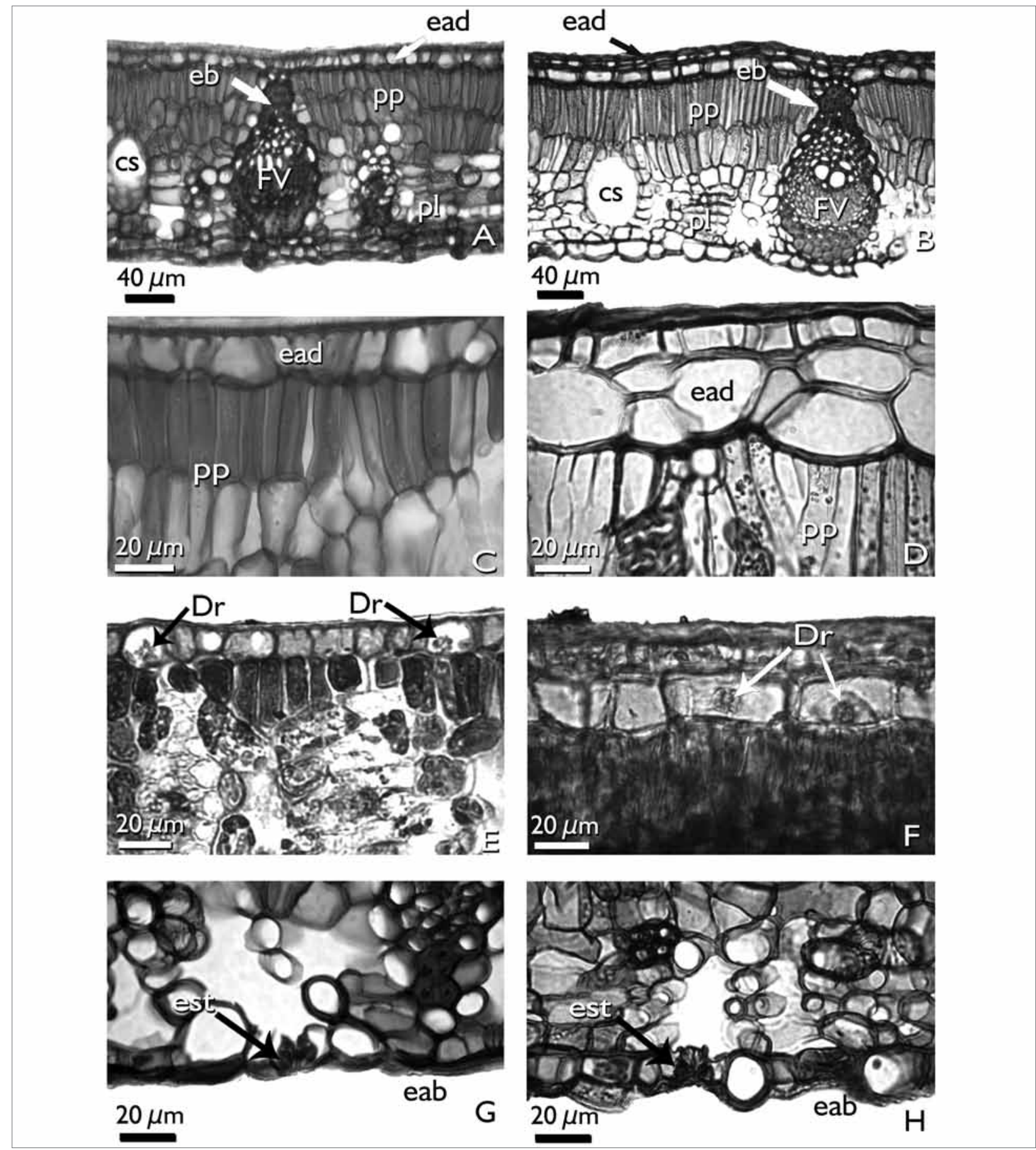

Figura 6. Secções transversais da lâmina foliar de Xylopia L.: A, C, E e G - X. benthamii. B, D, F e H - X. nitida. A e B - vista geral do mesofilo contendo cavidades secretoras e feixes vasculares com extensão de bainha; C e D - detalhe da epiderme adaxial; E e F - detalhe dos cristais em drusas inseridos nas células epidérmicas; $\mathrm{G}$ e H - detalhe da epiderme abaxial, evidenciando a posição dos estômatos em secção transversal. Extensão de bainha (eb). Cavidade secretora (cs). Drusas (Dr). Epiderme abaxial (eab). Epiderme adaxial (ead). Estômatos (est). Feixes vasculares (FV). Parênquima lacunoso (pl). Parênquima paliçádico (pp). 


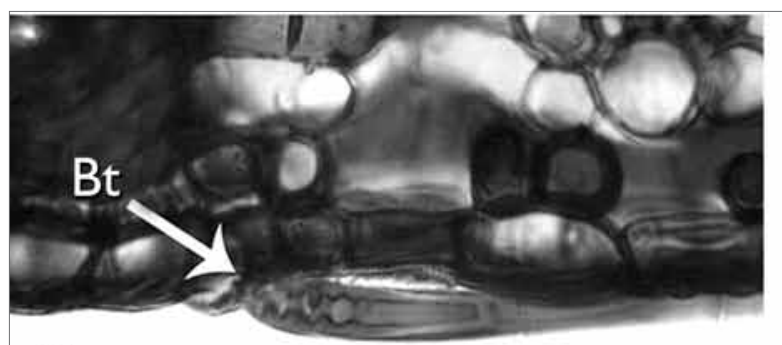

$20 \mu \mathrm{m}$

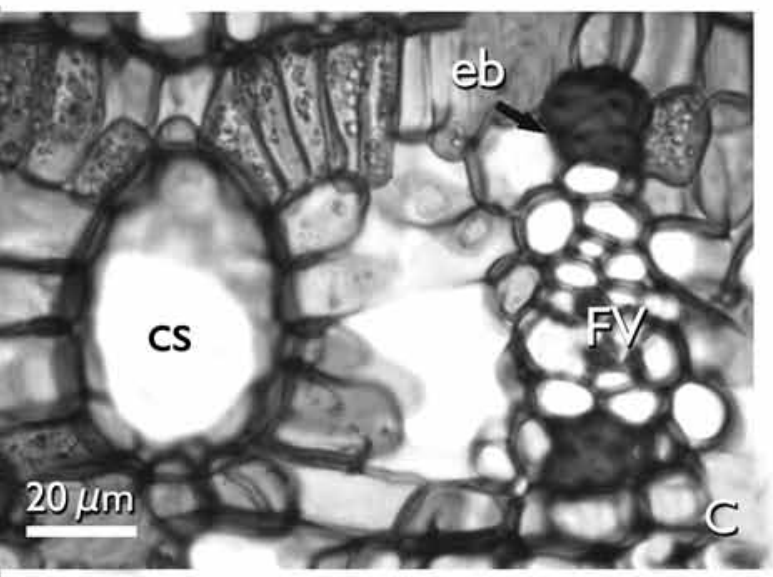

A $\quad 20 \mu \mathrm{m}$

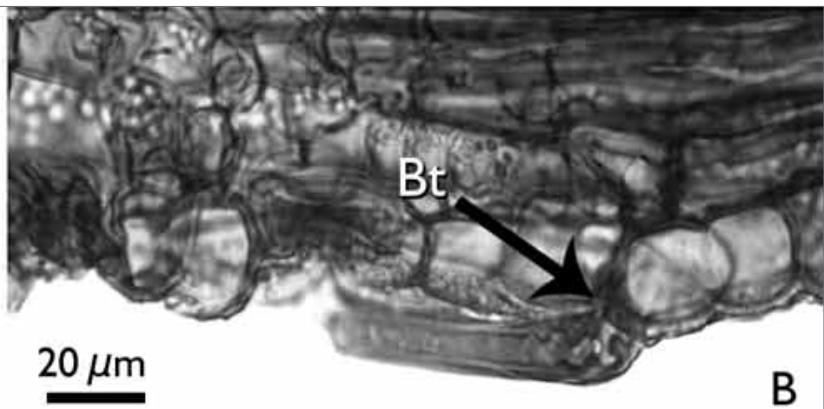

B
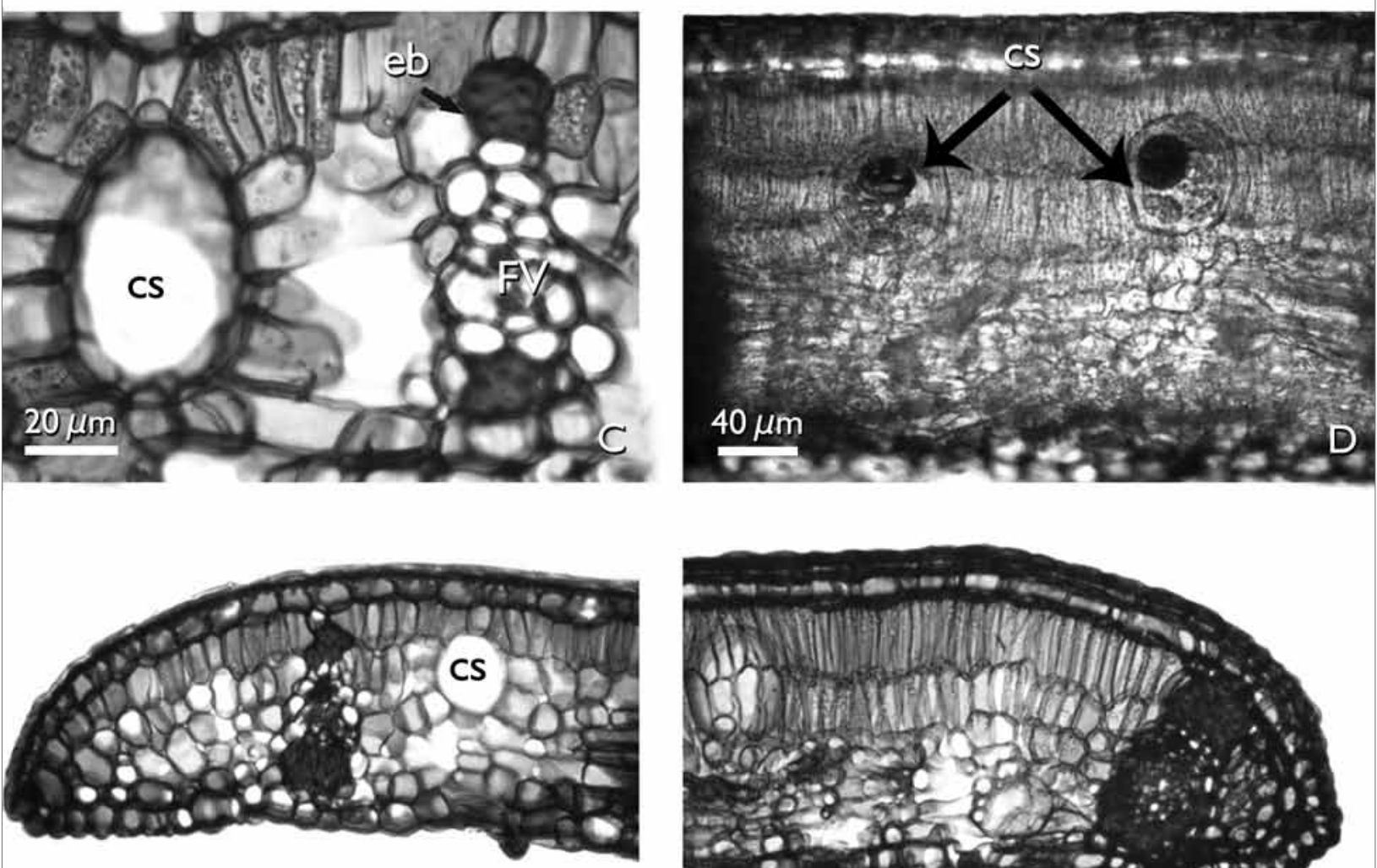

$40 \mu \mathrm{m}$

$\mathrm{E}$



Figura 7. Secção transversal da lâmina foliar de Xylopia L.: A, C e E - X. benthamii. B, D e F - X. nitida. A e B - detalhe da inserção dos tricomas em secção transversal; C - detalhe da cavidade secretora e feixe vascular no mesofilo; D - cavidades secretoras com conteúdo lipídico; E e F - vista geral da margem. Base do tricoma (Bt). Cavidade secretora (cs). Extensão de bainha (eb). Feixe vascular (FV).

\& Grotta (1975), em X. frutescens, denominaram essa estrutura de célula arredondada, e Santos et al. (2004) afirmam que estas são, na verdade, cavidades oleíferas em $X$. brasiliensis. Justos et al. (2005) definem estas estruturas como idioblastos oleíferos em X. brasiliensis. No presente trabalho, sugere-se que, para maior confiabilidade para se caracterizar esta estrutura, são necessários estudos ontogenéticos.

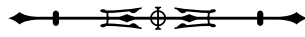


A região da margem foliar em secção transversal apresenta diferenças na organização do mesofilo entre as espécies estudadas. Em $X$. benthamii, percebe-se que o parênquima paliçádico reduz-se a uma camada, enquanto que e em $X$. nitida este parênquima continua biestratificado (Figura 7E e 7F). Nota-se que, em $X$. benthamii, o feixe vascular é reduzido e distante da margem (Figura 7E), enquanto que, em $X$. nitida, esta região é totalmente preenchida pelo feixe vascular envolvido por uma bainha esclerenquimática que reforça esta região (Figura 7F).

A nervura central das três regiões da lâmina foliar das espécies $X$. benthamii e $X$. nitida, em secção transversal (Figuras 8A e 8B), apresenta: região de revestimento (abaxial e adaxial), sistema vascular circundado por células parenquimáticas interrompidas pelo tecido colenquimático. No presente estudo, observa-se que o sistema vascular delimita a região medular. A epiderme adaxial é uniestratificada em $X$. benthamii (Figura $8 C$ ) e biestratificada em $X$. nitida (Figura 8D), enquanto que, na face abaxial, essas espécies são uniestratificadas e apresentam células epidérmicas de paredes anticlinais e periclinais espessadas (Figuras 8E e 8F). A cutícula dos taxa estudados é espessada na epiderme adaxial (Figuras 8C e 8D), enquanto que a epiderme abaxial é levemente espessada (Figuras 8E e 8F).

Adjacente à epiderme adaxial, observam-se células colenquimáticas que variam de uma a três camadas, com espessamento anelar em ambas as espécies (Figuras 8C e 8D). Eventualmente, na região basal da nervura central de $X$. benthamii, no parênquima que envolve o sistema vascular, são encontradas células pétreas (Figura 8G).

A nervura central dos taxa estudados apresenta o sistema vascular formado por um conjunto de feixes colaterais intercalados por raios parenquimáticos, os quais são envolvidos por uma bainha esclerenquimática descontínua (Figuras 8A, 8B e 8H).
A organização do sistema vascular das espécies estudadas também foi observada por Morretes \& Ferri (1959) para X. grandiffora, e por Silva \& Grotta (1975) para $X$. frutescens. Justos et al. (2005) encontraram tecido vascular envolvido por bainha esclerenquimática contínua em $X$. brasiliensis.

Observa-se que, em corte transversal, o pecíolo das espécies $X$. benthamii e $X$. nitida apresenta três regiões: de revestimento, cortical e vascular (Figuras 9A e 9B). Nota-se, ainda em secção transversal, que a face adaxial de $X$. benthamii apresenta uma invaginação conspícua (Figura 9A), enquanto que em $X$. nitida, na face adaxial, a mesma é levemente invaginada (Figura 9B).

A região de revestimento da face adaxial do pecíolo dos taxa estudados é formada por células irregulares, de diferentes tamanhos, podendo ocorrer, eventualmente, formato tabular e/ou quadrado, com paredes anticlinais retas e as paredes periclinais externas e internas côncavo-convexas em $X$. benthamii (Figura 9C). Em X. nitida, a parede anticlinal é reta, enquanto que a periclinal externa é papilosa e a interna é convexa (Figura 9D). A face abaxial, em ambas as espécies, possui células epidérmicas irregulares com paredes anticlinais e periclinais espessadas (Figuras 9E e 9F). A região cortical do pecíolo das espécies estudadas é preenchida por um parênquima fundamental (Figuras 9C e 9D). Entre as células do parênquima cortical ocorrem idioblastos em drusas, cavidades secretoras e aglomerados de células pétreas. Os idioblastos em drusas distribuem-se por todo o pecíolo e são constituídos por oxalato de cálcio, identificado por Chamberlain (1938) (Figuras 10A e 10B).

As cavidades secretoras observadas no pecíolo das espécies estudadas, as quais também foram observadas no mesofilo, estão distribuídas aleatoriamente, têm formas variadas e no seu interior observa-se conteúdo oleífero, identificado pelo teste Sudan III (Johansen, 1940) (Figuras 10C e 10D). Solereder (1908) e Metcalfe \& Chalk (1950) citam que as células secretoras 


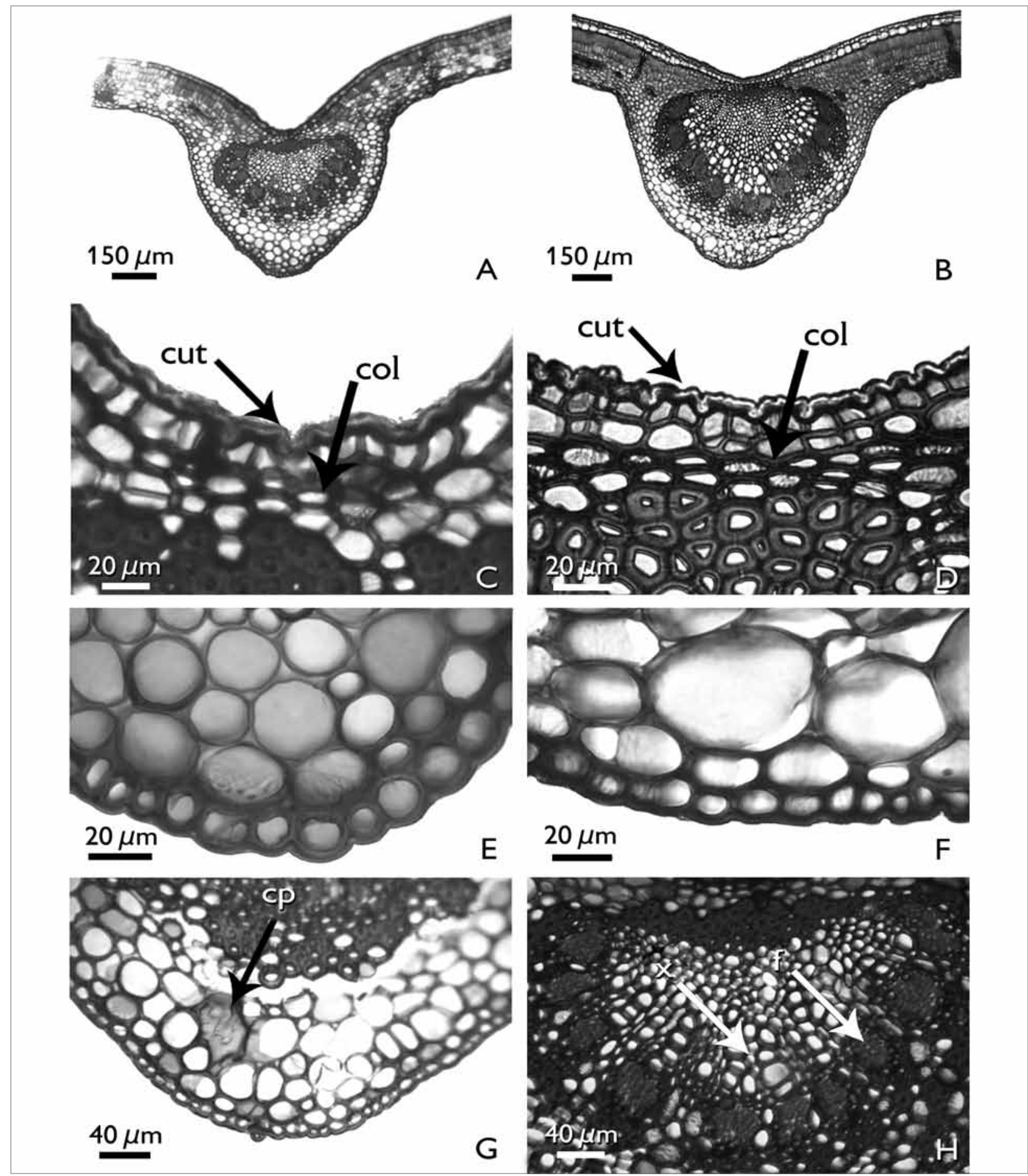

Figura 8. Secções transversais da nervura central da folha de Xylopia na região mediana. A, C, E e G - X. benthamii. B, D, F e H - X. nitida. A e B - vista geral; $C$ e D - detalhe das células epidérmicas adaxiais; $E$ e $F$ - detalhe das células epidérmicas abaxiais; $G$ - detalhe de células pétreas inseridas na região próxima à epiderme abaxial na base da folha; $\mathrm{H}$ - detalhe do feixe vascular. Células pétreas (cp). Colênquima (col). Cutícula (cut). Floema (f). Xilema (x). 


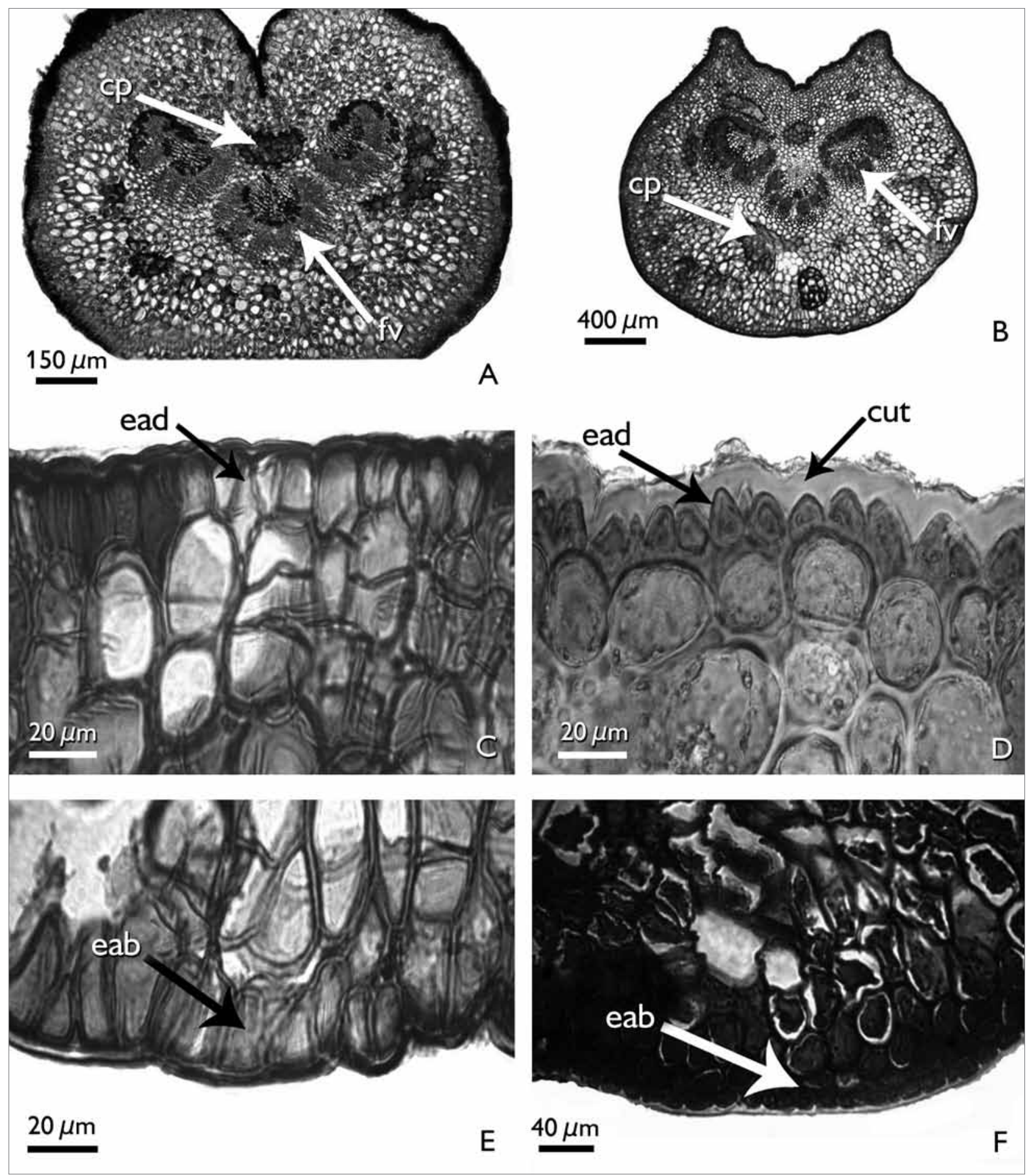

Figura 9. Pecíolo de Xylopia L., em secção transversal: A, C e E - X. benthamii. B, D e F - X. nitida. A e B - vista geral do pecíolo, evidenciando as regiões de revestimento, cortical e vascular; C e D - detalhe das células epidérmicas adaxiais; E e F - detalhe das células epidérmicas abaxiais. Epiderme abaxial (eab). Epiderme adaxial (ead). Células pétreas (cp). Cutícula (cut). Feixe vascular (fv).

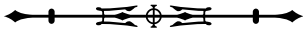



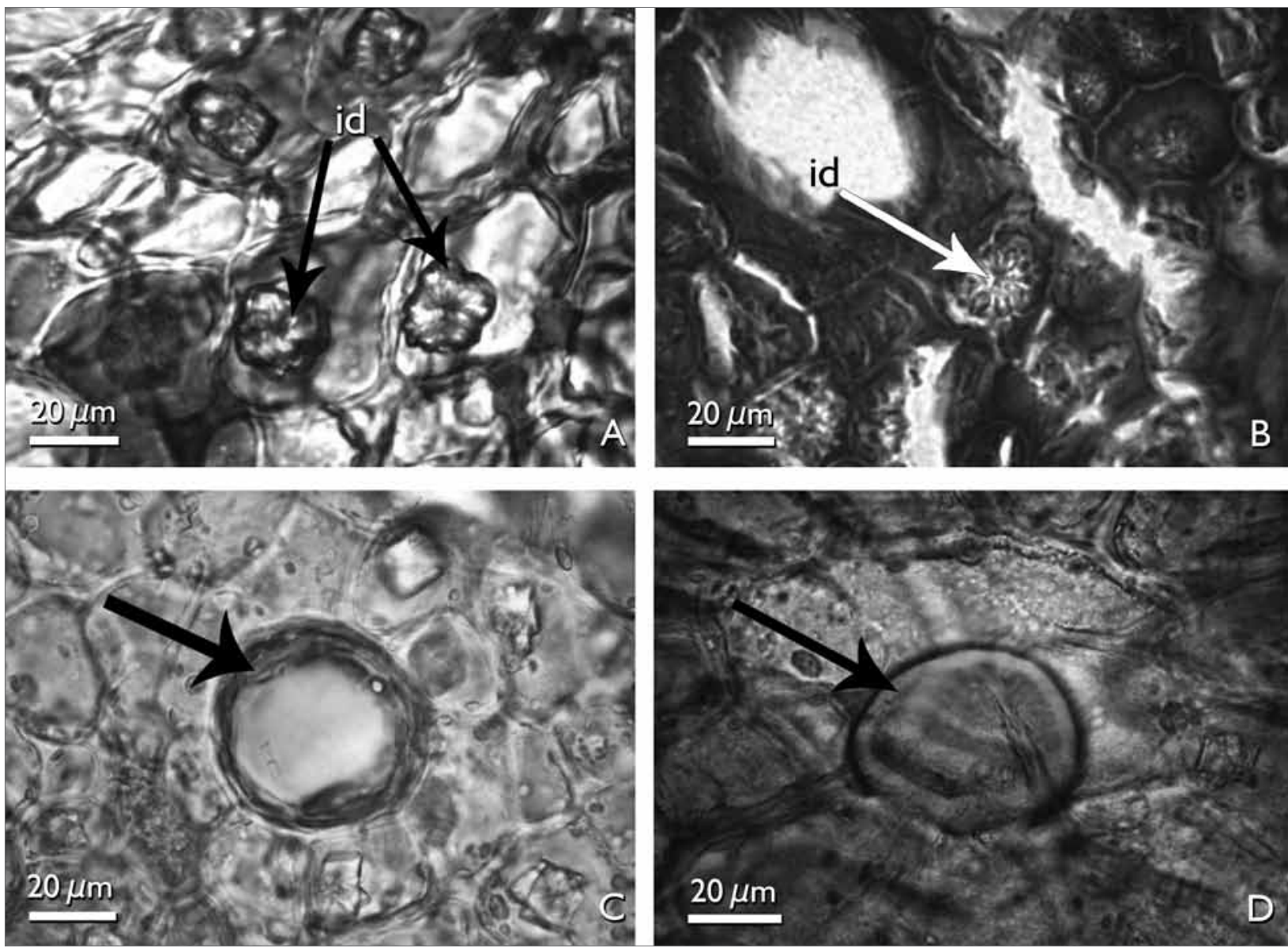

Figura 10. Detalhe de idioblastos em drusas e cavidades secretoras no pecíolo de espécies de Xylopia L.: A e C - X. benthamii. B e D - X. nitida. A e B - detalhe dos idioblastos em drusas; C e D - detalhe das cavidades secretoras. Idioblastos em drusas (id). Seta indica cavidades secretoras.

encontradas em espécies de Annonaceae são de natureza mucilaginosa e resinífera, fato que não foi observado nas espécies estudadas. Todavia, Santos et al. (2004), ao estudarem $X$. brasiliensis, identificaram as cavidades secretoras de natureza lipídica semelhantes aos resultados encontrados nas espécies estudadas.

As células pétreas encontradas no pecíolo de ambas as espécies estão geralmente agrupadas ou raramente isoladas, localizadas às proximidades do feixe vascular (Figuras 9A, 9B, 11A e 11B). A região vascular do pecíolo de $X$. benthamii e $X$. nitida situa-se na região central do mesmo, a qual é constituída por três traços foliares do tipo colateral (Figuras 9A e 9B). Estes traços se apresentam parcialmente ou totalmente envolvidos por uma bainha esclerenquimática lignificada e descontínua (Figuras 11C e 11D).

A arquitetura foliar das espécies estudadas apresenta nervura principal única, reta, afilando-se gradualmente no sentido da base para o ápice (Figuras 12A e 12E). Da nervura principal, partem 17 pares de nervuras secundárias em $X$. benthamii, enquanto que em $X$. nitida partem 18 pares de nervuras secundárias, as quais se unem, formando arcos sem atingir a margem da folha, caracterizando o tipo broquidódromo, o que corrobora os resultados encontrados por Chacur (1968) e Larroche (1973).

As nervuras de terceira ordem apresentam a organização poligonal em $X$. benthamii (Figura 12B) e

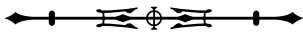



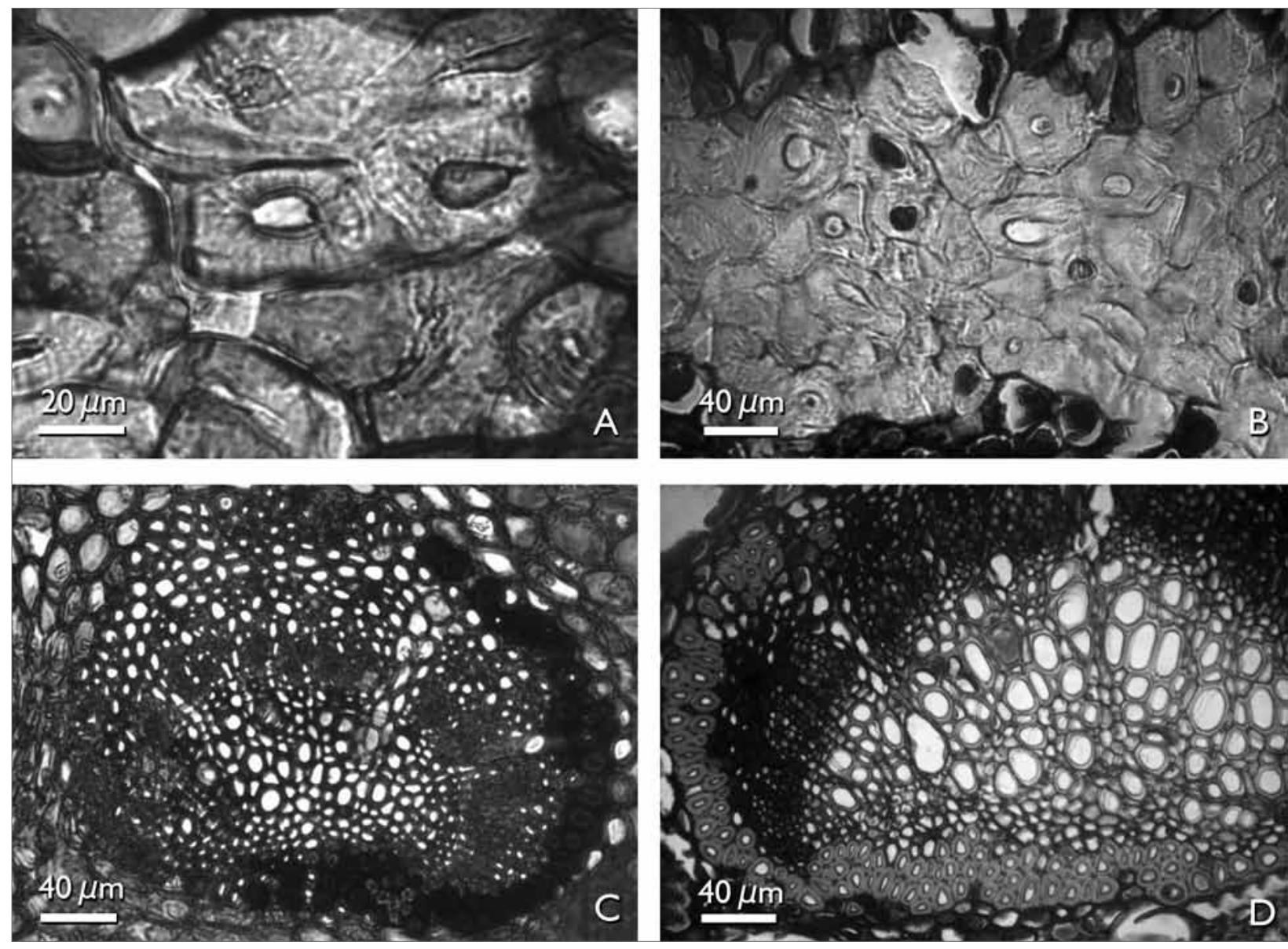

Figura 11. Detalhe dos agrupamentos de células pétreas e feixes vasculares das espécies de Xylopia L.: A e C - X. benthamii. B e D - X. nitida. A e B - detalhe dos agrupamentos de células pétreas; C e D: detalhe dos feixes vasculares.

percorrentes alternas em $X$. nitida (Figura 12F), sendo que estas nervuras de terceira ordem também partem da nervura principal (Figuras 12B e 12F). Percebe-se que, da nervura terciária, partem as nervuras de quarta grandeza, as quais atingem as nervuras secundárias, formando aréolas poligonais, que apresentam de quatro a seis lados em ambas as espécies (Figuras 12B e 12F).

As aréolas possuem terminações livres, simples ou bifurcadas (Figuras 12D e 12H). As terminações são constituídas de traqueídes múltiplos (Figuras 12D e 12H). A nervura marginal em $X$. benthamii é ausente (Figura 12C), enquanto que em $X$. nitida é presente e percorre todo o bordo foliar (Figura 12G).

\section{CONCLUSÕES}

Os dados obtidos no presente estudo revelaram que as espécies apresentaram caracteres anatômicos comuns à Annonaceae, como folha hipoestomática, tricomas simples, estômatos paracíticos, feixes vasculares colaterais, cavidades secretoras, padrão de venação do tipo broquidódromo e cera epicuticular escamosa.

Por meio do estudo anatômico, foi possível verificar a distinção dos taxa estudados em relação às seguintes características: paredes anticlinais sinuosas em $X$. benthamii e parede anticlinal reta em $X$. nitida; epiderme abaxial lisa em $X$. benthamii e papilosa em $X$. nitida; cutícula estriada na face abaxial de $X$. benthamii e lisa em

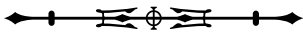




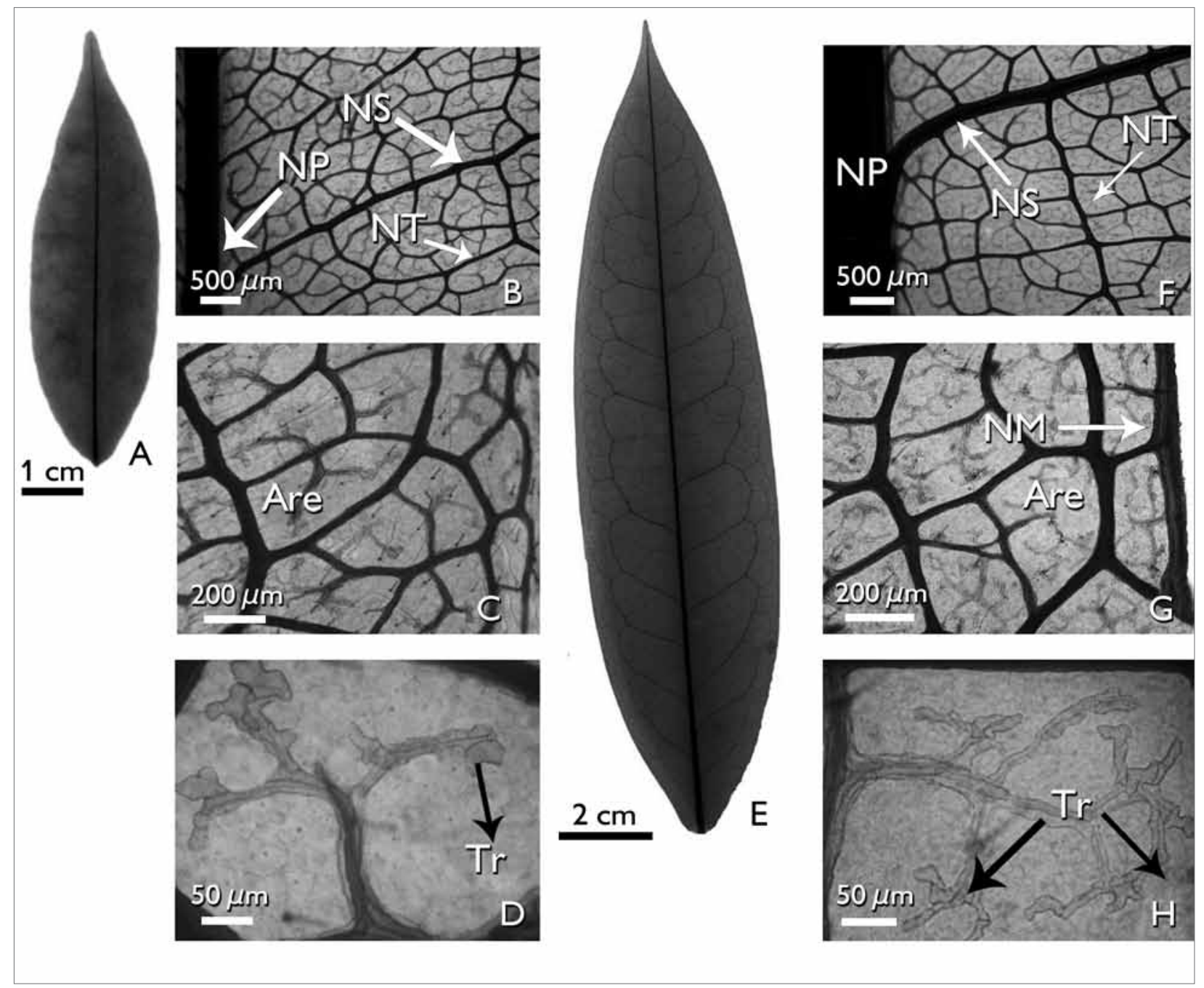

Figura 12. Venação foliar das espécies de Xylopia L.: A-D - Xylopia benthamii. E-H - X. nitida. A e E - vista geral da lâmina foliar; B e F detalhe das nervuras primária, secundária e terciária; C e G - detalhe das aréolas e da nervura marginal; D e H - detalhe das terminações vasculares, com a presença de traqueídeos. Aréolas (Are); Nervura primária (NP); Nervura secundária (NS); Nervura terciária (NT); Nervura marginal (NM); Traqueídeos (Tr).

$X$. nitida; região marginal terminando em feixe vascular em $X$. nitida e ausente em $X$. benthamii; e epiderme multisseriada em $X$. nitida e unisseriada em $X$. benthamii.

As cavidades secretoras de natureza lipídica foram observadas em ambas as espécies e estão localizadas em todo limbo foliar e no pecíolo de $X$. benthamii e $X$. nitida, sendo que estas estruturas não foram consideradas como um caráter taxonômico para a distinção das espécies.
A anatomia foliar das espécies $X$. benthamii e $X$. nitida constitui-se em uma ferramenta auxiliar na separação das mesmas.

\section{AGRADECIMENTOS}

Ao Conselho Nacional de Desenvolvimento Científico e Tecnológico (CNPq), pela concessão de bolsa à primeira autora; ao Projeto "Anatomia Vegetal: subsídios à taxonomia, fiscalização e produção vegetal", financiado pela

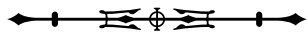


Pró-Reitoria de Pesquisa e Pós-Graduação da Universidade do Estado do Pará (PROPESP/UEPA); e à equipe do Laboratório de Anatomia Vegetal, da Coordenação de Botânica do Museu Paraense Emílio Goeldi.

\section{REFERÊNCIAS}

ALBARELLO, N., S. F. L. FIGUEIREDO, V. R. C. VIANA \& L. J. NEVES, 2001. Anatomia foliar de Rollinia mucosa (Jacq.) Baill. (Annonaceae) sob condições de cultivo in vivo e in vitro. Revista Brasileira de Plantas Medicinais 4(1): 35-46.

ALEXANDER, I. C., O. K. PASCOE, P. MARCHAND \& L. A. D. WILLIAMS, 1991. An insecticidal diterpene from Croton linearis. Phytochemistry 30: 1801-1803.

ALMEIDA, S. S., D. D. AMARAL \& A. S. L. SILVA, 2003. Inventário florístico e análise fitossociólogica dos ambientes do Parque Ecológico do Gunma, Município de Santa Bárbara, PA: 1-185. Relatório Técnico Final. Museu Paraense Emílio Goeldi, Belém.

ALQUINI, Y., C. BONA, M. R. T. BOEGER, C. G. COSTA \& C. F. BARROS, 2003. Epiderme. In: B. APEZZATO-DA-GLÓRIA \& S. M. CARMELLO-GUERREIRO (Eds.): Anatomia Vegetal: 1-438. UFV, Viçosa.

ARNOTT, H. J., 1959. Leaf clearings. Turtox News 37(8): 139-195.

CHACUR, F., 1968. Contribuição ao estudo da nervação foliar das Acanthaceae, Anacardiaceae e Annonaceae dos cerrados. Arquivos de Botânica do Estado de São Paulo 4(3): 141-152.

CHAMBERLAIN, C. J., 1938. Methods in plant histology: 5: 1-86. University of Chicago, Illinois.

CHATROU, L. W., H. RAINER \& P. J. M. MAAS, 2004. Annonaceae (Soursop Family). In: N. SMITH, S. A. MORI, A. HENDERSON, D. W. STEVENSON \& S. V. HEALD (Eds.): Flowering Plants of the Neotropics: 18-20. The New York Botanical Garden, New York.

CRONQUIST, A., 1981. An integrated system of classification of flowering plants: 53-55. Columbia University Press, New York.

GERLACH, D., 1984. Botanische Mikrotechnik: 1-311. Georg Thieme Verlag, Stuttgart.

JOHANSEN, D. A., 1940. Plant Microtechnique: 1-532. McgrawHill, New York.

JUSTOS, C. F., A. M. SOARES, M. L. GAVILANES \& E. M. CASTRO, 2005. Plasticidade anatômica das folhas de Xylopia brasiliensis Sprengel (Annonaceae). Acta Botanica Brasilica 19(1): 111-123.

KRAUS, J. E. \& M. ARDUIN, 1997. Manual básico de métodos em morfologia vegetal: 1-198. EDUR, Rio de Janeiro.
LARROCHE, R. C., 1973. Catálogo de nervação foliar das Amaranthaceae e Annonaceae da caatinga - III. Arquivos do Jardim Botânico do Rio de Janeiro 19: 269-279.

LEAF ARCHITECTURE WORKING GROUP, 1999. Manual of leaf Architecture: Morphological description and categorization of dicotyledonous and net-veined monocotyledonous angiosperms: 1-65. Department of Paleobiology, Smithsonian Institution, Washington.

LEÃO, N. V. M., A. D. D. FREITAS \& M. R. NASCIMENTO, 2005. Implantação da área de coleta de sementes: estudos fitossociológicos de florestas de terra firme: 1-80. Relatório Técnico Final. Embrapa Amazônia Oriental, Belém.

LEBOEUF, M., A. CAVÉ, P. K. BHAUMIK, B. MUKERJEE \& R. MUKHERJEE, 1982. The phytochemistry of the Annonaceae. Phytochemistry 21(12): 2783-2813.

METCALFE, C. R. \& L. CHALK, 1950. Anatomy of the Dicotyledons: 1: 1-724. Claredon Press, Oxford.

MONQUERO, P. A., P. J. CHRISTOFFOLETI, J. A. MATAS \& A. HEREDIA, 2004. Caracterização da superfície foliar e das ceras epicuticulares em Commelina benghalensis, Ipomoea grandifolia e Amaranthus hybridus. Planta Daninha 22(2): 203-210.

MORRETES, B. \& M. G. FERRI, 1959. Contribuição ao estudo da anatomia das folhas de plantas do cerrado. Boletim da Faculdade de Filosofia, Ciências e Letras da USP - série Botânica 16: 6-70.

OLIVEIRA, J., 1997. A Família Annonaceae Juss. In: P. L. B. LISBOA (Org.): Caxiuanã: 253-262. Museu Paraense Emílio Goeldi, Belém.

PATEL, R. J., 1971. Epidermal structure and development of stomata in some Annonaceae. Annals of Botany 35: 1205-1212.

RIBEIRO, J. E. L. S., M. J. G. HOPKINS, A. VICENTINI, C. A. SOTHERS, M. S. COSTA, J. M. BRITO, C. F. SOUZA, M. R. MESQUITA \& L. C. PROCÓPIO, 1999. Flora da Reserva Ducke. Guia de identificação das plantas vasculares de uma floresta de terra firme na Amazônia Central: 648-651. INPA, Manaus.

SANTOS, B. R., R. PAIVA, E. M. CASTRO, M. G. CARDOSO, R. K. S. REZENDE \& P. D. O. PAIVA, 2004. Aspectos da anatomia e do óleo essencial em folhas de pindaíba (Xylopia brasiliensis Spreng.). Ciência Agrotécnica 28(2): 345-349.

SILVA, J. B. \& A. S. GROTTA, 1975. Anatomia e óleo essencial das folhas de Xylopia frutescens Aublet. Boletim de Botânica da Universidade de São Paulo 3: 87-94.

SILVEIRA, M. O. O., 1989. Preparo de amostras biológicas para microscopia eletrônica de varredura. In: W. SOUZA (Ed.): Manual sobre técnicas básicas em microscopia eletrônica de varredura: técnicas básicas: 1: 71-82. Sociedade Brasileira de Microscopia Eletrônica, Rio de Janeiro. 
SOLEREDER, H., 1908. Systematic anatomy of the Dicotyledons: 2: 1078-1085. Clarendon Press, Oxford.

VIEIRA, R. C. \& D. M. S. GOMES, 1995. Superfície da lâmina foliar de Psychotria nuda (Cham. \& Schltdl.) Wawra, P. leiocarpa Cham. \& Schltdl., P. stenocalyx Müll. Arg. e P. tenuinervis Müll. Arg. (Rubiaceae). Acta Botanica Brasilica 9(2): 263-270.
WILKINSON, H. P., 1979. The plant surface (mainly leaf). In: C. R. METCALFE \& L. CHALK (Eds.): Anatomy of the Dicotyledons: 1(2): 97-165. Claredon Press, Oxford.

Recebido: 20/11/2008

Aprovado: 28/08/2009

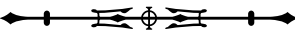

